\title{
船体各部から発生する素成波の伝播特性に 及ぼす局所流の影響
}

\author{
正員 中 村 重 郎* 正員 乾 崇 夫** \\ 正員梶谷尚**
}

Local Non-Linear Free Surface Effects for Hull Generating Elementary Waves

by Shigero Nakamura, Member Takao Inui, Member Hisashi Kajitani, Member

Summary

The local non-linear free surface effects acting upon hull generating elementary waves are surveyed. Through the simplification of the exact free surface condition, the basis of the non-linear theory, the low speed theory and the linear theory is characterized.

A non-linear wave theory developed as an extension of the geometrical optics is presented. The propagation of elementary waves generated on the hull from bow through stern is numerically traced. The non-linear effects integrated along the passage of waves in the non-uniform double body flow are discussed.

Based upon the asymptotical expression for free waves far rear the ship where the remained non-linear effects are taken into account, wave resistance is evaluated for an Inuid model. Less prominent humps and hollows of the calculated wave resistance coincide fairly well with the towing test results within the moderate Froude numbers.

\section{1 緒言}

船体造波の間題で往来広く用いられてきた線形理論 は，自由表面条件を線形化して得られた理論であるが近 年にいたって，その重大な欠陮が指摘されるようになっ だ。すなわち自由表面条件の線形化は, 結果として船 の排除効果が波の発生伝播に与える影響を無視してい ることが明らかになった。粘性の影響を度外視しても， 実験から得られる造波抵抗係数曲線は，薄い船から有限 の幅を有する船になるに応じて, 線形理論による予測よ りはるかに小さいハンプホローを示し，横波成分が著し く小さくなることが知られている2)。線形理諭の体内に 止まり，これを補正する形で実際とのギャップを埋めよ らとする試み汭は以前にもかなりなされてきたが，この 種の手段には扮のずと限界があり, 設計者が意図すると おりの造波干渉を起こさせ，波の少ない船型を求める理 論としては不充分である。

歪栾標を朋いたり，特別の座標变換によって実際の非 線形な造波場（物理空間）を線形な薄い船の場（思考空

* 日立造船(株)本社造船基本設計部

*** 東京大学工学部
間）に写像させて考学るものとして Guilloton 法4)が, また，波の表示は線形波動の重㸚合わせとするが，振幅 決定の過程に自由表面条件の非線形項の影響を取り入れ る，馬場，丸尾の低速造波理論があげられる。これらは 線形性のもたらす利便さを保持してな蛙非線形影響を含 ませようとするものであるが，波形の非線形性を表わし ていない点がどう影響するか問題である。

著者らは先に屈折率が連続して变化する媒質内の光波 を扱う幾何光学の考えを基礎に，局所流の影響を考慮し た新しい造波理諭の展開を試みだう。船体まわりの局所 流は低速に怙いては二重模型流れであるとし, 船首波と 船尾波が伝播の過程で受ける“ゆがみ”を明らかにし， 局所影響を含む造波抵抗算定式を提案した。さらに幅シ リーズの 3 隻の Inuid 模型 M 6, M 7, M 8 の造波抵抗 を求め船幅の増大とともに強くなる非線形影響が，中低 速において実験結果ともかなりよく対応することが明ら かとなった。

船のつくる波は巨視的には船首尾からのみ発生してい るよらにみえ, 事実低速に拈いては船首尾端の形状が波 および造波抵抗を決定する要因となるが，実際には船体 の各位置から出る波が寄せ集まって上記のように見える。 
この意味からすれば上記の造波抵抗算定法は, 船体各部 から出る波に船首尾波に対する局所影響を適用したこと になり近似的な処理といえる。

本研究は船体各部から出る波の伝播特性を 3 隻のなか で最も幅の広いM８ 亿ついて求め, 造波に対するより 精確な局所非線形影響を考察したものである。

\section{2 非線形自由表面条件}

敩密な自由表面条件から出発し, その簡略化の過程を 通して船体造波に打ける局所非線形影響の物理的意味を 考察する。一定速度 $U_{0}$ で進む船に座標系をおき，船長 船尾方向に $x$ 軸を，鉛直上方に $z$ 軸，これらに直角に $y$ 軸をとり，船による自由表面の変形を $z=\boldsymbol{\zeta}(x, y)$, 船体 まわりの流速を $\boldsymbol{U}(u, v, w) （ u$ は一様流 $U_{0}$ を含む）と すると自由表面上の物理的条件・運動学的条件から,

$$
\begin{gathered}
U_{0}^{2} / 2=g \boldsymbol{\zeta}+P / 2 \\
\boldsymbol{\zeta}_{x} \cdot u+\boldsymbol{\zeta}_{y} \cdot v-w=0
\end{gathered}
$$

ただし $P=u^{2}+v^{2}+w^{2}$ ， suffix $x, y$ は偏微分を表わす。 （1）式を $x, y$ で微分（2）式に代入して $\zeta_{x}, \zeta_{y}$ を消 去すると厳密な自由表面条件式が得られる。

$$
2 g w+u \cdot P_{x}+v \cdot P_{y}+w \cdot P_{z}=0, \quad(\text { on } z=\zeta)
$$

(3) 式はこのままでは解くことがむずかしいので, 物理 的特性をなるべく生かした形での簡略化をはかる。問題 を低速に限り，自由表面の变位が微小であると仮定すれ ば, 船体まわりには二重模型流場 $\boldsymbol{U}_{r}\left(u_{r}, v_{r}, w_{r}\right)$ が形成 され，(3）の係数では $2 g>u>v>w$ の順に小さくな り $w \cdot P_{z}$ や，第 2 , 第 3 項の $w \cdot w_{x}, w \cdot w_{y}$ は省略して よいと考兄られる。これより低速の自由表面条件式が得 られる。

$$
g w+u^{2} u_{x}+u v\left(u_{y}+v_{x}\right)+v^{2} v_{y}=0, \quad(\text { on } z=\boldsymbol{\zeta})
$$

（4）式で $v$ を無視し，uは浪注 $U$ 。゙代表できるとす

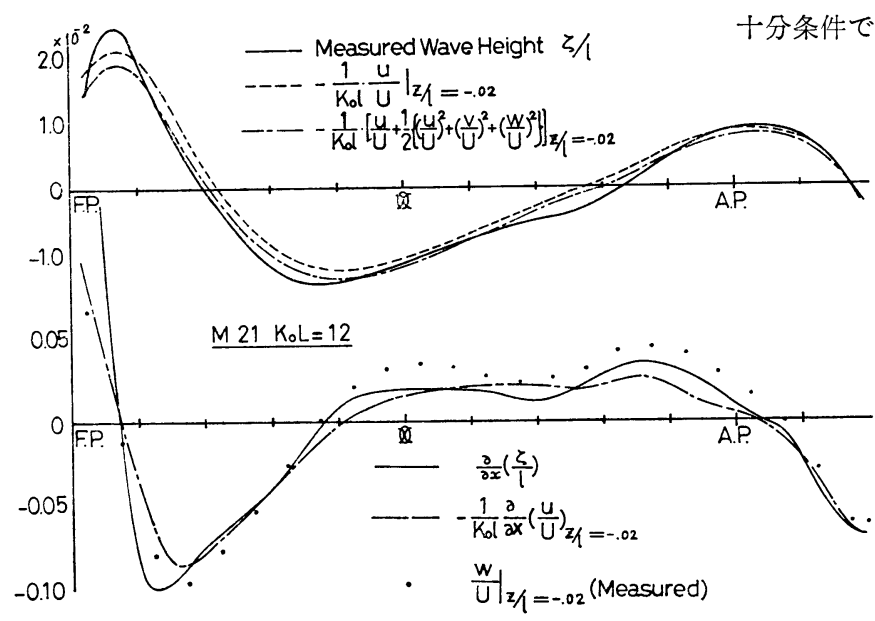

Fig. 1 Comparison of $(u, \zeta)$ and $\left(w, \zeta_{x},-u_{x}\right)$

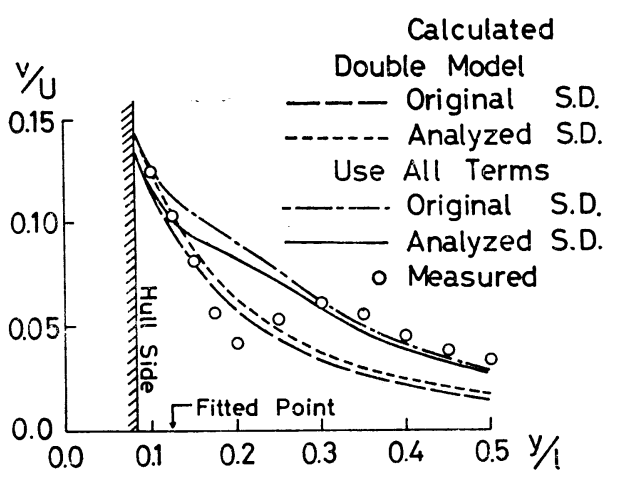

Fig. 2 Comparison of $v$ on lateral line $(x / l=-0.45, z / l=-0.04)$

れば, 従来の線形自由表面条件式が得られる。

$$
g w+U_{0}^{2} u_{x}=0, \quad(\text { on } z=0)
$$

著者の一部は, かつて船体近傍の流速・波高を実測し （1）式（5）式の条件が現実にどの程度成り立つもの か，また横方向の流速 $v$ を計測し，（5）式を満たす線形 理論による計算値とどの程度合うかを検討した ${ }^{8), 9)}$ (Fig. $\left.1,2, U=U_{0}\right)$ 。著者らは

（1）Fig. 1 によって自由表面条件の線形化は許され る仮定である。

（2） Fig. 2 におけるvの実測結果が理論と異なる原 因は自由表面条件の線形化以外飞帰すべきであ る。

と結論したが，これは重大な過ちであった。Fig.1のよ らな比較で仮に $\zeta / l$ (実測) と $-\left(k_{0} l\right)^{-1} \cdot u / U$ (実測), あ るいは $\partial / \partial x(\boldsymbol{\zeta} / l)$ (実測) と $w / U$ (実測) が一致したと しても，船体排除効果による局所流の曲がりの影響はか くれて explicit には出てこない。すなわち Fig. 1 の比 較でこれらが一致したからといって線形化の仮定が許さ れるとするのは早計であった。(必要条件ではあっても 十分条件ではなかった。）速度場 $(u, v, w)$ も波形（， $\partial \zeta / \partial x)$ もすべて同じ場所での実測值と理 論値とを比較して，その一致の程度を調べ る必要がある。この意味では Fig. 1 より も Fig. 2 の比較法の方がより正しい情報 を与古るものといってよい。当時われわれ は自由波成分に対する船体の排除効果は船 型を表わす特異点分布で十分表現されてい ると考光，線形理論と実流場との不一致は それ以外の原因 (例宇ば line integral) によるものと考劣ていた。しかしその後, 堤・日下らの研究により, line integral の影響の本質があきらかになると同時に， 排除効果が直接，（4）式の第 $3 ， 4$ 項によ って造波の機構そのものに影響すること， 
線形条件の（5）式では排除効果がまったく無視されて いることを再認識するにいたった。

ここで上記の論文ならびにこれに続いて発表した論文 における誤りを指摘しておく。

文献 8 : 高次船型の流場解析（造論 135 号, 1974, 5

頁, 下から 16 行目)

現在の造波抵抗理論が実際の造波現象を必らずし も十分忠実に再現しえない主たる理由は，少なくと も自由表面条件の線形化にあるのではなく，その原 因は他に求めるべきである。

文献 9 : Velocity Field Measurements Applied for Analysis of Ship's Wave-Making Singlarities (10 th ONR Symp. 1974, p. 554 left col., 4 lines from below)

The main reasons why the present theory of wave making resistance cannot necesarily give the enough explanation to the actual wave making phenomenon should not be attributed at least to the linearization of free surface conditions

文献 10 : 局部流を考慮した航走波の解析（造論 138 号, 1975, 40 頁, 上から 2 行目)

線形化された 2 種類の白由表面条件は実流場にお いてほぽ正しく成立している。

文献 11: Hull Form Design, Its Practice and Theoretical Background (ISWR, 1976, p. 178, left col. 12 lines from below)

Same with Ref. 9

もとに戻って (4) 式を満足する解を求める。速度成 分を二重模型流速と波動項に分け $\left(u=u_{r}+u^{\prime}, \cdots \cdots\right)$, Ogilvie $\left.{ }^{12}\right)$ がボした低速での波の属性を入れて簡略化す ると,

$$
\begin{aligned}
g\left(w_{r}+w^{\prime}\right) & +u_{r}^{2}\left(u_{r x}+u_{x}^{\prime}\right)+2 u_{r} v_{r}\left(u_{r y}+u_{y}^{\prime}\right) \\
& +v_{r}^{2}\left(v_{r y}+v_{y}^{\prime}\right)=0, \quad\left(\text { on } z=\zeta_{r}\right)
\end{aligned}
$$

ダッシュを削り，既知の項を右辺に移すと，

$$
\begin{aligned}
& g w+u_{r}^{2} u_{x}+2 u_{r} v_{r} u_{y}+v_{r}^{2} v_{y} \\
& \quad=-g\left(w_{r}+u_{r}^{2} u_{r x}+2 u_{r} v_{r} u_{r y}+v_{r}^{2} v_{r y}\right) \\
& =g \cdot D(x, y), \quad\left(\text { on } z=\zeta_{r}\right)
\end{aligned}
$$

ただし

$$
\begin{gathered}
D(x, y)=\left(\zeta_{r} \cdot u_{r}\right)_{x}+\left(\zeta_{r} \cdot v_{r}\right)_{y} \\
\zeta_{r}=\left(U_{0}^{2}-u_{r}^{2}-v_{r}^{2}\right) / 2 g
\end{gathered}
$$

馬場ら ${ }^{5)}$ および Newman ${ }^{13)}$ が導いた式が得られ， これは低速造波理論 (Low Speed Wave Resistance Theory) の出発点となる式である。

さらに線形理論の立場まで簡略化してみる。(4) 式で 新記号 $\boldsymbol{v}(u, v, w) \rightarrow \boldsymbol{v}\left(U_{0}+u^{\prime}, v^{\prime}, w^{\prime}\right) \rightarrow \boldsymbol{v}\left(U_{0}+u, v, w\right)$ を 用いると,

$$
g w+1 / 2 \cdot\left(\overline{U_{0}+u} \cdot \partial / \partial x+v \cdot \partial / \partial y\right) \cdot\left(\overline{U_{0}+u^{2}}+v^{2}\right)=0
$$

すなわち

$$
\begin{aligned}
& g \cdot w+U_{0}^{2} \cdot u_{x}+2 U_{0} u \cdot u_{x}+u^{2} \cdot u_{x}+2 \overline{U_{0}+u} \cdot v \cdot u_{y} \\
& \quad+v^{2} \cdot v_{y}=0, \quad(\text { on } z=\zeta)
\end{aligned}
$$

従来の線形理論を適用するため, 上式の第 1,2 項に含 まれる波動項のみを残し他を二重模型の流速 $\left(u_{r}, v_{r}\right)$ で 近似すると,

$$
\begin{aligned}
g \cdot w+U_{0}^{2} u_{x}= & -U_{0}^{2} u_{r x}-1 / 2 \cdot \overline{\left(2 U_{0}+u_{r}\right.} \cdot \partial / \partial_{x} \\
& \left.+v_{r} \cdot \partial / \partial_{y}\right)\left(u_{r}^{2}+v_{r}^{2}\right) \\
& -w_{r z} / 2 \cdot\left(2 u_{r}+u_{r}^{2}+v_{r}^{2}\right),(\text { on } z=0)
\end{aligned}
$$

となり丸尾の準線形的取扱いの式と一致する。

局所非線形影響を含む自由表面条件は（4）式，（7） 式であって，これらの式の左辺第 3,4 項，つまり船の 排除効果を無視すれば線形理論の非斉次問題としての （12）式が得られる。馬場は（7）式から出発したが造波 抵抗を求める段階で結果的に上記排除効果を省略したた め，(12）式と同じ解を得た。（12）式を満足する波動の 造波機構には局所流の影響は含まれておらず, 線形な解 に非線形項のもつ量的影響を加えた形で問題が処理され ている。このように非線形問題を線形化して扱う場合, 物理特性がそこなわれないかどうかよく検討しておく必 要がある。

\section{3 幾何光学からみた造波現象}

船体造波の非線形現象，とくに波の伝播特性は幾何光 学の考觉でよく説明できる。排除効果のない均一流場で は, 一つの波（素成波）は規則正しい一定の波長で直線 的に伝播するが, 局所流があると波の屈折が起こる。定 常の波動関数 $\phi(x, y, t)$ の振幅を $A(x, y)$, 位相を $\varphi$ $(x, y), k_{0}$ を基本波数として次のよらに表わし，

$$
\phi(x, y, t)=A(x, y) \cdot \exp \left[i k_{0}\{c t+\varphi(x, y)\}\right]
$$

媒体の不均一度を $n(x, y)$ とした波動方程式,

$$
\partial^{2} \phi / \partial t^{2}=c^{2} / n^{2} \cdot \nabla^{2} \phi
$$

に代入すると

$$
\begin{gathered}
k_{0}^{-2} \cdot \Delta A+i k_{0}^{-1}\{2(\nabla A \cdot \nabla \varphi)+A \Delta \varphi\} \\
-A\left\{(\nabla \varphi)^{2}-n^{2}\right\}=0
\end{gathered}
$$

$k_{0}$ が大きいとき，すなわち低速では幾何光学における アイコナル方程式 $(\nabla \varphi)^{2}=n^{2}(x, y)$ が得られる ${ }^{14)}$ 。(13) 式で $\omega=k_{0} c$ とし $\phi$ の周期項を分離 $\phi=\exp (i \omega t) \cdot \Phi$ と書けば，(14）式は時間に依存しないSchrödinger の 波動方程式

$$
\left\{\nabla^{2}+k_{0}^{2} n^{2}(x, y)\right\} \Phi(x, y)=0
$$

となる。このとき $n(x, y)$ は場所に応じてゆっくり変化 する二重模型流場に対応する。 $n(x, y)=1$ のときは均 一流場の波の伝播を与える。 


\section{1 線形波動場}

均一流場での波動は Helmholtz の式で与えられる,

$$
\left\{\nabla^{2}+k_{0}^{2}\right\} \Phi(x, y)=0
$$

船の波は重力による表面波であり，水平に伝播するとす る。このとき $\phi(x, y, z)$ を速度ポテンシャルとし, 変数 分離で $\phi=\phi_{1}(x, y) \cdot \phi_{2}(z)$ とおくと, $\Delta \phi=0$ より,

$$
\begin{aligned}
& {\left[\left\{\left(\frac{\partial^{2}}{\partial x^{2}}+\frac{\partial^{2}}{\partial y^{2}}\right)+k_{0}^{2}\right\}+\left\{\frac{\partial^{2}}{\partial z^{2}}-k_{0}^{2}\right\}\right]} \\
& \times \phi_{1}(x, y) \cdot \phi_{2}(z)=0
\end{aligned}
$$

これより

$$
\begin{aligned}
& \begin{aligned}
\phi_{1}(x, y) & =\exp \left\{i k_{0} \varphi(x, y)\right\} \\
& =\exp \left\{i k_{0}(x \cos \theta+y \sin \theta)\right\}
\end{aligned} \\
& \phi_{2}(z)=\exp \left(k_{0} z\right)
\end{aligned}
$$

(18)，(19）式を線形自由表面条件（5）式に代入すると,

$\left(i k_{0} \cos \theta\right)^{2} \phi(x, y, z)+g / U_{0}^{2} \cdot k_{0} \phi(x, y, z)=0$

あるいは $k_{0}=g / U_{0}^{2} \cdot \sec ^{2} \theta=K_{0} \sec ^{2} \theta$, これより素成波の 速度ポテンシャルは $A$ を振幅として,

$\phi(x, y, z)=A \cdot \exp \left[K_{0} \sec ^{2} \theta\right.$

$$
\{z+i(x \cos \theta+y \sin \theta)\}]
$$

全体として,

$$
\begin{array}{r}
\phi(x, y, z)=\int_{-\pi / 2}^{\pi / 2} A(\theta) \exp \left[K_{0} \sec ^{2} \theta\right. \\
\times\{z+i(x \cos \theta+y \sin \theta)\}] d \theta
\end{array}
$$

\section{2 非線形波動場}

局所流がある場合は (15) 式の波動方程式が支配する。 このとき $\phi=\phi_{1}(x, y) \cdot \phi_{2}(x, y, z)$ とおくと，

$$
\begin{aligned}
\left\{\left(\frac{\partial^{2}}{\partial x^{2}}\right.\right. & \left.+\frac{\partial^{2}}{\partial y^{2}}\right)+k_{0}^{2} n^{2}(x, y)+\frac{\partial^{2}}{\partial z^{2}} \\
& \left.-k_{0}^{2} n^{2}(x, y)\right\} \phi_{1}(x, y) \cdot \phi_{2}(x, y, z)=0
\end{aligned}
$$

$\phi_{2}(x, y, z)$ の解として次のようにおく,

$$
\phi_{2}(x, y, z)=\exp \left\{k_{0} \cdot n(x, y) \cdot z\right\}
$$

Schrödinger の場を満足する $\phi_{1}(x, y)$ の位相関数 $\varphi(x$, y）がわかったとすれば,

$$
\phi_{1}(x, y)=\exp \left\{i k_{0} \varphi(x, y)\right\}
$$

これらを(23) 式に代入,

$$
\begin{gathered}
k_{0} n^{2}-k_{0}\left[(\nabla \varphi)^{2}-2 i z\left(\varphi_{x} n_{x}+\varphi_{y} n_{y}\right)\right. \\
\left.-z^{2} n^{3 / 2}(\nabla n)^{2}\right]=0
\end{gathered}
$$

$n(x, y)$ は slowly varying であるから $n \gg n_{x}, n_{y}$ と すると，

$$
n^{2}(x, y)=(\nabla \varphi)^{2}
$$

速度ポテンシャルは,

$$
\phi(x, y, z) \equiv \exp \left[k_{0}(|\nabla \varphi| z+i \varphi)\right]
$$

これを非線形の自由表面条件式（4）に代入，最低次の 項のみとると,

$$
k_{0}=g|\nabla \varphi| /\left(u_{r} \varphi_{x}+v_{r} \varphi_{y}\right)^{2}=g \sqrt{\varphi_{x}^{2}+\varphi_{y}^{2}} /\left(\boldsymbol{v}_{r} \cdot \nabla \varphi\right)^{2}
$$

$\nabla \varphi /|\nabla \varphi|$ は波頂線に垂直な方向の単位ベクトルで， $\left(\boldsymbol{v}_{r}\right.$. $\nabla \varphi) /|\nabla \varphi|$ は二重模型流場 $v_{r}$ の波頂に直角の成分とな るから，これを $V_{r n}$ と表わすと局所波数は，

$$
k=k_{0} n(x, y)=k_{0}|\nabla \varphi|=g / V_{r n}^{2}
$$

波頂線が $x$ 軸となす角をととすれば $V_{r n}=u_{r} \sin \gamma-v_{r}$ $\cos \gamma=c_{p}$ (位相速度) となって，局所波数が局所流速で 決まることがわかる。

このよらに連続の条件, 波動方程式, 自由表面条件式 から, 自由波の解の形式 (27) 式が求められ, Ursell の 仮定が得られることがわかる。 $\boldsymbol{v}_{r}\left(u_{r}, v_{r}\right)$ は船のはるか 後方で一様流 $\left(U_{0}, 0\right)$ となり，そこでの位相関数を $\varphi_{\infty}$ と記せば, 波の屈折, 伸縮はなく, 速度ポテンシャル $\phi_{\infty}$ は漸近的に次のよらに表わされる。

$$
\begin{gathered}
\varphi_{\infty}(x, y)=x \sin \gamma_{\infty}-y \cos \gamma_{\infty} \\
k_{\infty}=g /\left(U_{0} \sin \gamma_{\infty}\right)^{2} \\
|\nabla \varphi|=1 \\
\phi_{\infty}(x, y, z)=\int_{-\pi / 2}^{\pi / 2} A\left(\theta_{0}\right) \exp \left[k _ { \infty } \left\{z+i\left(x \sin \gamma_{\infty}\right.\right.\right. \\
\left.\left.\left.-y \cos \gamma_{\infty}+\varepsilon\right)\right\}\right] d \theta_{0}
\end{gathered}
$$

ここに $A\left(\theta_{0}\right)$ は素成波 $\theta_{0}$ が発生時に有していた波振 幅, また均一流場では $\gamma\left(x, y, \theta_{0}\right)=r_{0}\left(\theta_{0}\right)=\pi / 2+\theta_{0}$ と なる。

（31）式は形式においては線形理論と同じであるが，局 所流があるときは, 波の伝播とともに, 波頂傾斜 $\gamma(x$, $\left.y, \theta_{0}\right)$ や位相 $\varphi\left(x, y, \theta_{0}\right)$ に特性曲線に沿う, 通過残存 効果が起こるため異なってくる。局所影響は単に船体ま わりのみでなくはるか後方に及ぶのであって，写像や歪 座標で線形理論の波模様を局所流の部分だけ丕ませただ けでは通過残存効果はでてこない。

\section{4 解析}

船体各部から発生する素成波の伝播特性を計算し，ヶ ルビンパターンおよび造波抵抗を算定し実測と比較す る。これらの解析を通して船体造波に打ける局所非線形 影響を考察する。

\section{1 供試 船 型}

解析は単純 Inuid 船型 M 6, M 7, M 8 のらち, 最も 幅の広いM 8 について行なった。本船型の等価特異点 分布は次式によって与光られる。

$$
\begin{gathered}
4 \pi m\left(\xi^{\prime}, \zeta^{\prime}\right)=-2.50105 \xi^{\prime}+2.28210 \xi^{\prime 3} \\
-1(\mathrm{FP}) \leq \xi^{\prime} \leq 1(\mathrm{AP}) \\
-0.08 \leq \zeta^{\prime} \leq 0
\end{gathered}
$$

\section{2 波動伝播特性}

船体まわりには二重模型流場が形成され，この局所流 中を波が伝播するとして, 波頂線の変化, 波動エネルギ 一の伝播軌跡を求めた。計算は S.S. 10 (FP), $7 \frac{1}{2}, 5$, $21 / 2 ， 0(\mathrm{AP})$ から出る素成波について行なった。結果を Fig. 3a〜3e に示す。図には線形理論による伝播特性も 


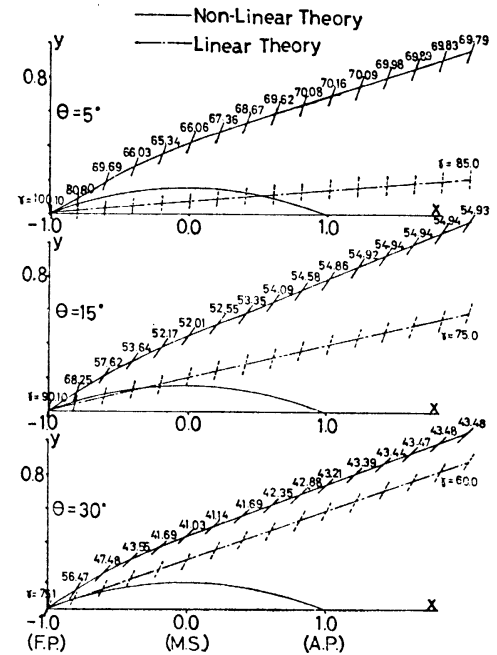

(a)

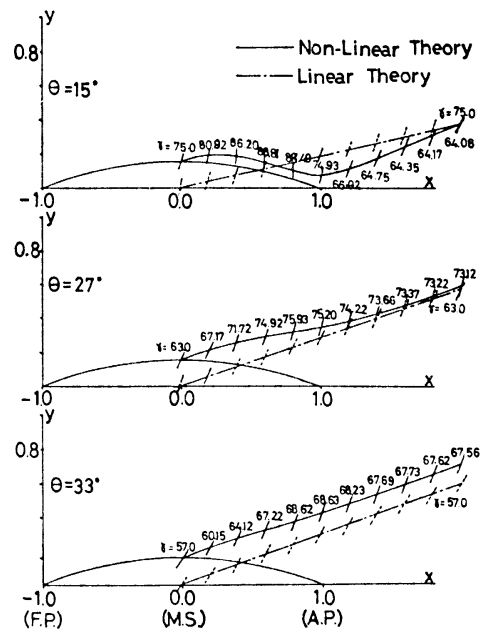

(c)
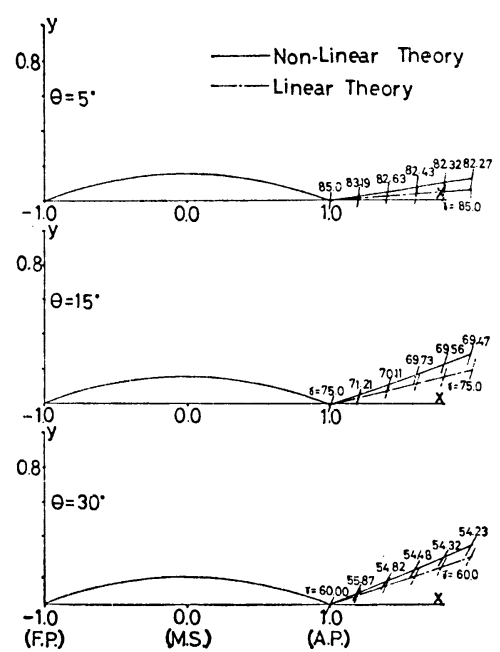

(e )
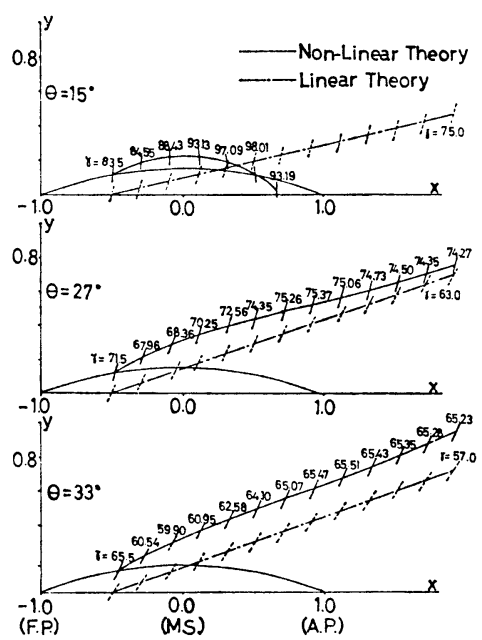

( b )

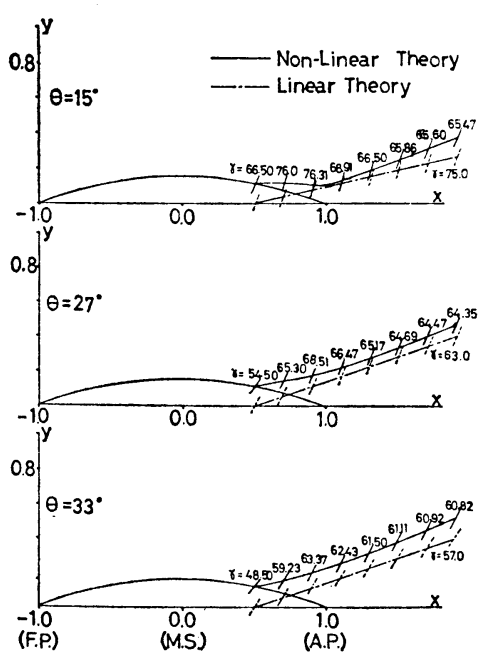

(d)
Fig. 3a Elementary wave with crest angle from FP (M 8)

Fig. $3 b$ Do from SS $7^{1 / 2}$

Fig. 3c Do from SS 5

Fig. $3 \mathrm{~d}$ Do from SS $2 \frac{1}{2}$

Fig. $3 \mathrm{e}$ Do from AP 
示す。船首横波は外方にずれ，波頂線は $x$ 軸方向に傾斜 している。同様の傾向は船尾波にもみられる。しかし， これらの中間から発生する素成波については逆の傾向が みられる。

\section{3 ケルビン波}

局所波数は局所流速で決まるので，波動エネルギー伝 播曲線に沿って位相を計算した。局所流を無視した場合 は各素成波のもつ波長は一定で規則正しい配列の位相面 が現われ，ケルビン波と呼んでいる。これに対し局所流 がある場合は一つの素成波でも，伝播の過程で波長が変 化し等間隔とならないため,ゆがんだケルビン波が得ら
れる。その模様を横波成分について Fig. $4 \mathrm{a} \sim 4 \mathrm{c}$ に示 す。これらの図からも船首波が外方に, 中間波が内側に くることがわかる。Fig. 5 は実測波紋と船首波のケルビ ン波（山谷）の比較図である。局所流の影響を考慮した 非線形ケルビン波が実測の八字波とよく合っていること がわかる。

\section{4 造 波特 性}

局所非線形影響を含む自由波の速度ポテンシャルは, (31) 式の形で漸近表示されることがわかった。造波抵抗 を求めるには船固有の振幅関数を知る必要がある。本解 析では船の造波特異点について次のように考え造波抵抗

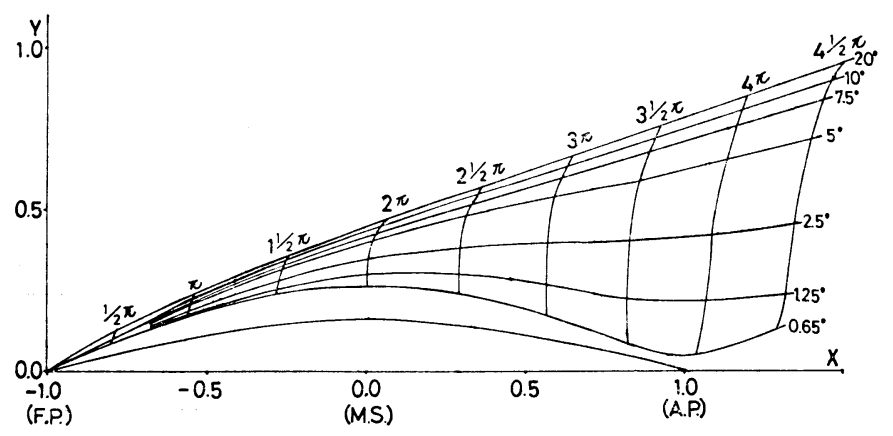

Fig. 4a Deformed Kelvin pattern from FP (M 8, $\left.K_{0} L=12\right)$

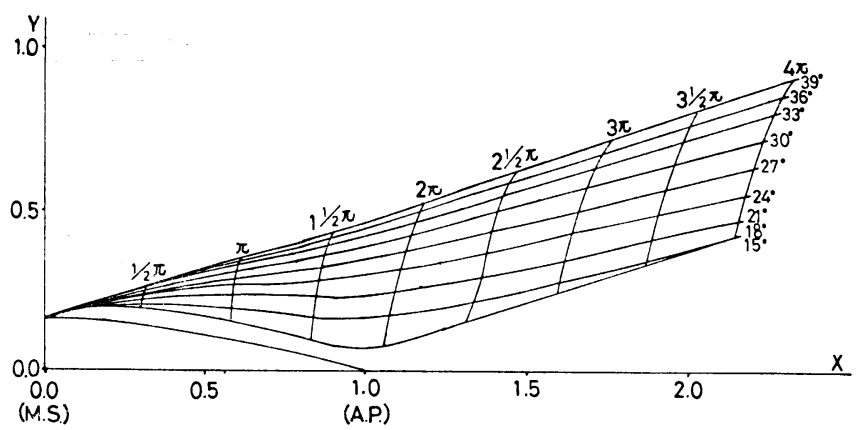

Fig. 4 b Do from SS 5

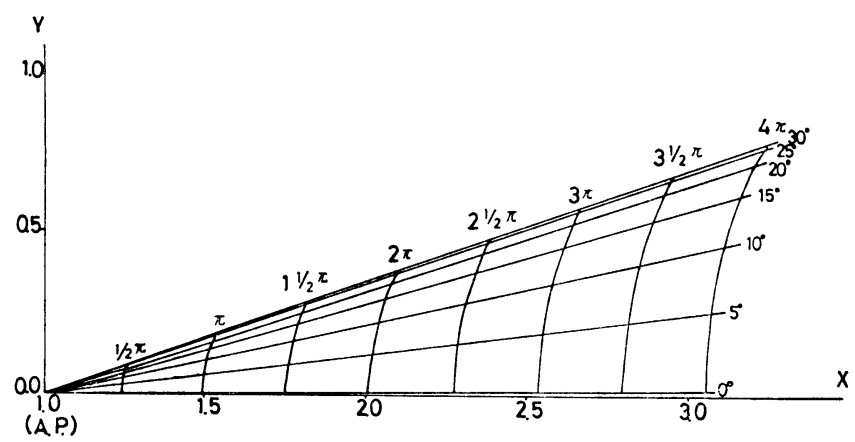

Fig. 4c Do from AP 


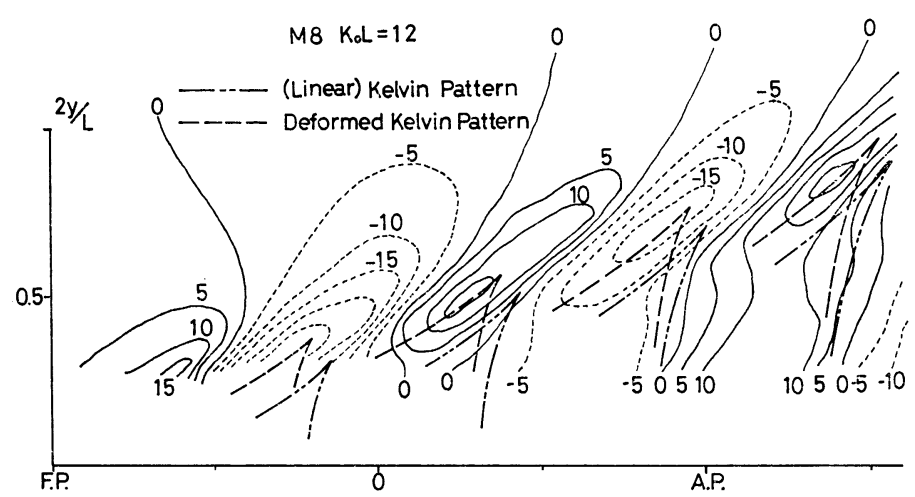

Fig. 5 Measured wave contours and calculated Kelvin patterns

を求めた。はるか後方の船の波は（31）式の線形なパタ ーンであり，船体からここにいたるまでは波動エネルギ 一保存則が成立つと考兄られる。とすれば局所影響を受 けたこれらの波は，結局はるか後方の線形な波のパター ンに必要とされる波動エネルギーが波源で供給されてい ることになる。すなわち（31）式に漸近する線形な自由 波の速度ポテンシャル $\phi_{F}$ を考学ると，

$$
\begin{aligned}
\phi_{F}= & -4 \int_{-l}^{l} \int_{-t}^{0} m(\xi, \zeta) d \xi d \zeta \int_{-\pi / 2}^{\pi / 2} \frac{K_{0}}{\sin ^{2} \gamma_{\infty}} \\
& \cdot \exp \left[K_{0} \overline{z+\zeta} / \sin ^{2} \gamma_{\infty}\right] \\
& \cdot \sin \left[\frac { K _ { 0 } } { \operatorname { s i n } ^ { 2 } \gamma _ { \infty } } \left\{(x-\xi) \sin \gamma_{\infty}-y\right.\right. \\
& \left.\left.\cdot \cos \gamma_{\infty}+\varepsilon\left(\theta_{0}, \xi\right)\right\}\right] d \theta_{0}
\end{aligned}
$$

ここで $\gamma_{\infty}=\gamma_{\infty}\left(\theta_{0}, \xi\right)$ の逆関数を用いると（以下 $\infty を$ 略), $\theta_{0}=H(\gamma, \xi), d \theta_{0}=[d H(\gamma, \xi) / d \gamma] d \gamma$, 変数変換 $\gamma=\pi / 2+\theta$ を行ならと $d \theta_{0}=[d H(\gamma, \xi) / d \theta] d \theta,(33)$ 式 は次式のようになる。

$$
\begin{aligned}
\phi_{F}= & -4 \int_{-l}^{l} \int_{-t}^{0} m(\xi, \zeta) d \xi d \zeta \int_{-\pi / 2}^{\pi / 2} \frac{d H(\theta, \xi)}{d \theta} \\
& \cdot K_{0} \sec ^{2} \theta \cdot \exp \left(K_{0} \cdot \overline{z+\zeta} \sec ^{2} \theta\right) \\
& \cdot \sin \left[K_{0} \sec ^{2} \theta\{\overline{x-\xi} \cos \theta+y \sin \theta\right. \\
& +\varepsilon(\theta, \xi)\}] d \theta
\end{aligned}
$$

（34）式には，各素成波が伝播過程で受けた通過残存効果 に基号き, 素成波重み関数 $d H(\theta, \xi) / d \theta$ と位相差関数 $\varepsilon(\theta, \xi)$ を含んでいる点が線形理論と異なる。これまで は (34) 式で $H(\theta, \xi), \varepsilon(\theta, \xi)$ の $\xi$ にる変化は小さ いとして船首尾位置での関数を適用していた7)。今回 これらのほによる変化を考察した。Fig. 3 から得た $d H(\theta, \xi) / d \theta$ を Fig. 6a 飞, 線形非線形ケルビン波の比 較から得た $\varepsilon(\theta, \xi)$ を Fig. $6 \mathrm{~b}$ と示す。ただし線形ケ ルビン波も船体表面から出るとして位相差を求めた。

\section{5 振幅関数と造波抵抗}

（34）式の速度ポテンシャルから自由波を求め重率振 幅関数を求めた（Fig. $7 \mathrm{a}, \mathrm{b})$ 。比較のため図には, 線形

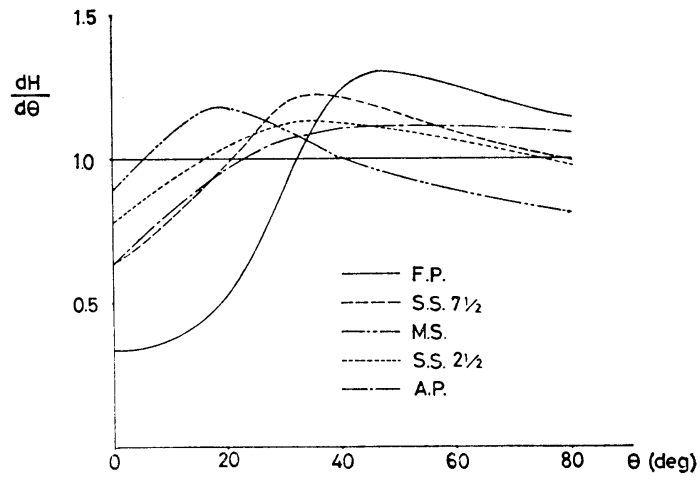

Fig. 6a Weighting function for elementary waves (M 8)

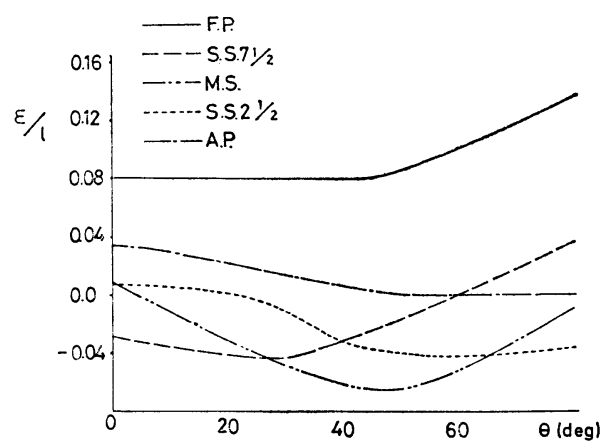

Fig. $6 \mathrm{~b}$ Function of phase shift for elementary waves (M 8)

理論による結果，船首尾波に対する非線形影響を適用し た結果, 拈よび $N-S$ 法による実測波形解析結果も示し た。今回の方法は実測波形の解析結果に近く, 横波も目 立たなくなっていることがわかる。船首尾波の重み関数 を適用した結果と今回の方法とでは，いくらか今回の方 が実測に近いといえるかも知れない。さらに造波抵抗係 数を求めた (Fig. 8)。今回の結果が $F_{n}=0.3$ 以下で水 槽試験結果に近いことがわかる。本計算には，船尾に拉 


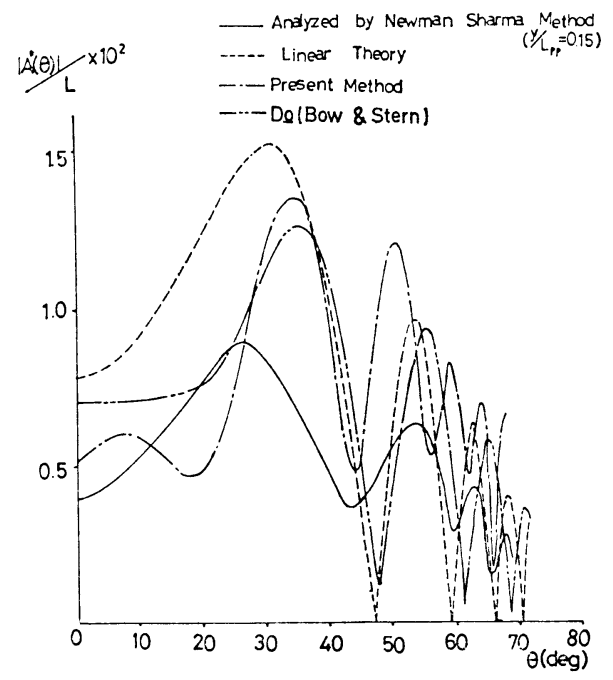

Fig. $7 \mathrm{a}$ Weighed amplitude functions (M 8, $K_{0} L=12$ )

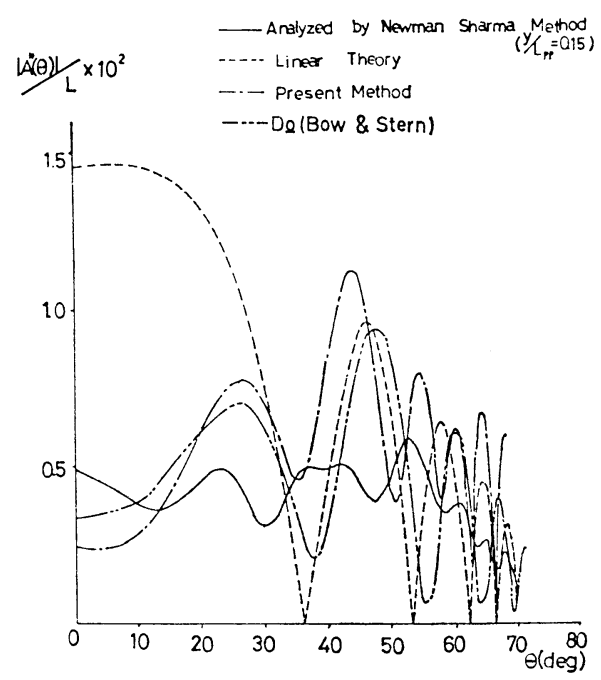

Fig. $7 \mathrm{~b}$ Do $\left(\mathrm{M} 8, K_{0} L=14\right)$

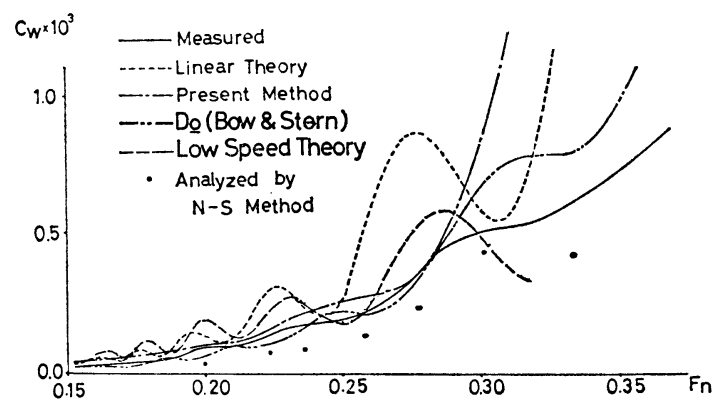

Fig. $8 \quad C_{w^{-}}-F_{n}$ Curves (M 8)
ける粘性影響は含まれて和らず，もし粘性影響を考慮す ればさらに実測に近づくことが期待される。な技 $F_{n}>$ 0.3 以上で, 実験結果と異なってくるのは本理論が波長 の短い幾何光学的特性に根ざしたものであるためで適用 範囲は低㴡に限られるものと考兄られる。

\section{5 結言}

（1）絞密な自由表面条件式の簡略化の過程を通し て, 定常造波に拈ける局所非線形影響を考察し, 船自身 の排除効果が自由表面条件を介して造波の非線形泩を招 くことを指摘した。

（2）幾何光学の考えを基化，低速汇括ける船の非線 形造波の説明を試みた。

（3）船体各部から発生する素成波の伝播特性を計算 し波の “ゆがみ”を明らかにし, 造波特性に影響する素 成波重み間数, 位相美関数を求め, 局所影響を考慮した 造波抵抗曲線を求め, $F_{n}<0.3$ において, 実测結果と比 較的よい一致をみた。

本研究を実施するにあたって，第 4 章の計算は高橋雅 之・宮本 篤両工学士に担当していただいた。また本研究 は一部文部省の科研費に, 計算は東大大型計算機によっ た。関係各位に厚くお礼申しあげます。

\section{参考文 献}

1) Inui, $T$. : Introductory Remarks, Int. Seminar on Wave Resistance (ISWR), Tokyo (1976).

2) 乾 崇夫, 梶谷 尚：単純船型の船首波波形解析, 日本造船学会論文集, 124 号 (1968).

3）茂里一絴, 乾崇夫, 棍谷尚: 船側波形化上る 造波特性解析とその船型計画への応用, 日本造船 学会論文集, 132 号 (1972).

4) Gadd, G.E. : Wave Resistance Calculations by Guilloton's Method, TRINA, Vol.115 (1973).

5) Baba, E. and Takekuma, K. : A Study on Free Surface Flow around Bow of Slowly Moving Full Forms, JSNA Japan, Vol. 137 (1975).

6) Maruo, H. : Wave Resistance of a Ship with Finite Beam at Low Froude Numbers, Bulletin of Fac. of Eng., Yokohama National University, Vol. 26 (1977).

7) Inui, T. and Kajitani, H. : A Study on Local Non-Linear Free Surface Effects in Ship Waves and Wave Resistance, Schiffstechnik, Bd 24 (1977).

8）北沢孝宗, 乾 崇夫, 暒谷 尚: 高次船型の流場 解析, 日本造船学会論文集, 135 号 (1974).

9) Kitazawa, T., Inui, T. and Kajitani, H. : Velocity Field Measurements Applied for Analysis of Ship's Wave-Making Singularities, 10 th ONR Symp. Cambridge (1974). 
10）岡村英邦, 乾 崇夫, 棍谷 尚：局部流を考慮し た航走波の解析, 日本造船学会諭文集, 138 号 (1975).

11) Inui, T. and Kajitani, H. : Hull Form Design, Its Practice and Theoretical Background, ISWR, Tokyo (1976).
12) Ogilvie, T.F. : Wave Resistance: The Low Speed Limit, The U. of Michigan (1968).

13) Newman, J. N. : Linearized Wave Resistance Theory, ISWR, Tokyo (1976).

14) Born, M. : Optik, Springer Verlag, Berlin (1933). 